\title{
Retrospective analysis of patients who admitted to the emergency service with orthopedic injuries
}

\author{
Gökhan Ersunan ${ }^{a *}$, Mustafa Uslu ${ }^{b}$, Yavuz Geçer, Yavuz Katirci ${ }^{c}$, Hayati Kandis ${ }^{d}$, Özlem Bilir ${ }^{a}$, Ayhan Saritas $^{\mathrm{d}}$ \\ ${ }^{a}$ Department of Emergency Medicine, Faculty of Medicine, Recep Tayyip Erdoğan University, Rize, Turkey \\ ${ }^{b}$ Department of Orthopedic and Traumatology Surgery, Faculty of Medicine, Düzce University, Düzce, Turkey \\ ${ }^{c}$ Department of Emergency Medicine, Ankara Teaching and Research Hospital, Ankara, Turkey \\ ${ }^{d}$ Department of Emergency Medicine, Faculty of Medicine, Düzce University, Düzce, Turkey
}

\section{Article History}

Received $\quad 18 / 09 / 2013$

Accepted 25/10/2013

\section{* Correspondence to:}

Gökhan Ersunan

Department of Emergency,

Faculty of Medicine,

Recep Tayyip Erdoğan University,

Rize, Turkey

e-mail: gokhanersunan@gmail.com

\section{Keywords:}

Emergency service

Extremity trauma

Multiple trauma

Orthopedic injury

\begin{abstract}
The purpose of this study is to determine the demographic characteristics of forensic reported patients who entered to emergency service with orthopedic injuries, the problems of doctors responsible for these people's treatment and to contribute the extremity trauma data literature in our country during 12 months. Between 1 January 2010-31 December 2010; In the Duzce University School of Medicine Research and Training Hospital Emergency Department treated and examined 600 patients who were forensic reported and have orthopedics injuries (soft tissue injury, fractures, dislocations, tendon injury, skin and subcutaneous incision, vascular- nerve injuries and amputations) were analyzed from computer data and forensic reports. Quantitative data were presented with mean \pm standard deviation, while qualitative data were presented as frequencies and percentages. For the analysis of categorical variables Chi-square test (and/or Fisher's exact test) was chosen. Four hundred sixty eight patients (78\%) were male and $132(22 \%)$

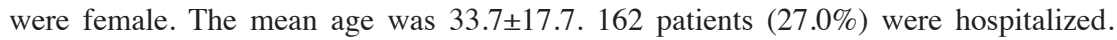
Patients hospitalized mostly in the orthopedics clinic $(n=90,55.6 \%)$, second in plastic surgery $(n=57,35.2 \%)$. All of the types of injuries were seen more frequently in males, and this difference was statistically significant $(\mathrm{p}<0.001)$. A large number of patients discharged from the emergency department $(n=431,71.8 \%), 2(0.3 \%)$ patients were unfortunately lost. Extremity trauma cases brought to the emergency room for trauma has to be known by a special case by medical doctors, more comprehensive medical history should be taken and physical examination should be done systematically not only for the extremities. Also the following or needing control in early period patients with extremity trauma and associated traumas should not be avoided from hospitalization
\end{abstract}

J. Exp. Clin. Med., 2013; 30:335-338

\section{Introduction}

Trauma is the main cause of deaths between the ages of 1-44 (Regel et al., 1995; Kandis et al., 2009). The most common causes of trauma are traffic accidents, falls, assault, firearms or penetrating injuries, child and the elderly abuses. Deaths due to trauma rank third among all age groups deaths (Jones, 1980; Kandis et al., 2009). Isolated extremity trauma is rarely causes death and disability with adequate and timely intervention. Orthopedic trauma injuries may be isolated or in conjunction with other system injuries as well (Bayram, 2013). Orthopedic injury-related deaths are often seen with uncontrolled external bleeding. Sometimes large bone fractures may cause silent internal bleeding and this may be life threatening.

Extremity traumas may be seen blunt and/or penetrating traumas. In the hospital and pre-hospital early diagnosis and treatment is very important for orthopedics trauma as important as all traumas. 
In this study, over a period of 12 months in all age groups held in the emergency department, the applicant and the forensic report to determine demographic characteristics of patients with orthopedic injuries, evaluation and treatment of patients in the hospital physicians, who are responsible for the process, and ultimately evaluate the problems extremity trauma data was to contribute to the literature of in Turkey.

The purpose of this study is to determine the demographic characteristics of forensic reported patients who entered to emergency service with orthopedic injuries, the problems of doctors responsible for these people's treatment and to contribute the extremity trauma data literature in Turkey during 12 months.

\section{Materials and methods}

Between 1 January 2010 - 31 December 2010, in the Düzce University School of Medicine Research and Training Hospital Emergency Department treated and examined 600 patients who were forensic reported and have orthopedics injuries (soft tissue injury, fractures, dislocations, tendon injury, skin and subcutaneous incision, vascular- nerve injuries and amputations) were analyzed from computer datas and forensic reports.

Cases are evaluated by gender, age, time of application groups (08:00-16:00, 16:00-24:00, 24:00-08:00), mechanism of injury (traffic accidents, falls, assault, penetrating injury), be fixed or not with simple medical treatment, work accident or not, a life-threatening situation, as a result of treatment of patients with emergency room (ER) status after examination (discharge, referral, hospitalization or death) and the hospitalized services.

\section{Statistical evaluation}

The obtained data is recorded to "Statistical Package for Social Sciences 15.0 for Windows" (SPSS-15) computer package program and analyzed. Quantitative datas were presented as mean \pm standard deviation, while qualitative data were presented as frequencies and percentages. Chi-square(and / or Fisher's exact test) test was used for the analysis of categorical variables. Results were given as mean \pm SD and value of $\mathrm{p}<0.05$ was considered statistically significant.

\section{Results}

There was 600 patients who had orthopedic injuries enrolled in the study. Four hundred and sixty eight patients (78\%) were male and $132(22 \%)$ were female. The mean age was $33.7 \pm 17.7$ (minimum 1, maximum 87). Demographic characteristics of the patients are shown in Table 1 .

One hundred and sixty two patients $(27.0 \%)$ were hospitalized. Most hospitalized clinic was orthopedics $(n=90$, $55.6 \%)$, secondly followed by plastic surgery $(n=57,35.2 \%)$. The other patients hospitalized to $15(9.2 \%)$ in the intensive care unit because of their associated injuries, general surgery, pediatric surgery clinics were followed.

All of the types of injuries were seen more frequently in males, and this difference was statistically significant $(\mathrm{p}<0.001)$. Similarly, men were more applicants due to accidents at work $(p<0.001)$. Soft tissue injury, tendon injury, the skin and subcutaneous incision, blood vessel-nerve injuries and amputations were more frequently in men but only the fractures were more common in women. Dislocations ob-
Table 1. Demograhic properties of patients

\begin{tabular}{|c|c|c|c|}
\hline Characteristics of patients & & N / Med. & $\% / \mathrm{SD}$ \\
\hline Age & & 33.7 & 17.7 \\
\hline \multirow{3}{*}{ Gender } & Male & 468 & 78.0 \\
\hline & Female & 132 & 22.0 \\
\hline & 00:00-08:00 & 80 & 13.3 \\
\hline \multirow[t]{3}{*}{ Application-hour groups } & 08:00-16:00 & 249 & 41.5 \\
\hline & $16: 00-24: 00$ & 271 & 45.2 \\
\hline & Traffic accident & 234 & 39.0 \\
\hline \multirow{3}{*}{ Mechanism of injury } & Fall & 102 & 17.0 \\
\hline & Assault & 74 & 12.3 \\
\hline & Penetrating injury & 190 & 31.7 \\
\hline \multirow{2}{*}{ Work accident } & Yes & 113 & 18.8 \\
\hline & No & 487 & 81.2 \\
\hline \multirow{2}{*}{ With SMI } & May be Removed & 310 & 51.7 \\
\hline & May not be removed & 290 & 48.3 \\
\hline \multirow{2}{*}{ Life Threatening } & Yes & 45 & 7.5 \\
\hline & No & 555 & 92.5 \\
\hline \multirow{4}{*}{ Outgrowth } & Discharged & 431 & 71.8 \\
\hline & Hospitalization & 162 & 27.0 \\
\hline & Referral & 5 & 0.8 \\
\hline & Exitus & 2 & 0.3 \\
\hline \multirow[t]{7}{*}{ Diagnosis } & Skin-Subcutan Insicion & 185 & 30.8 \\
\hline & Fracture & 170 & 28.3 \\
\hline & STI & 161 & 26.8 \\
\hline & Tendon Insicion & 42 & 7.0 \\
\hline & Amputation & 30 & 5.0 \\
\hline & Vessel-Nerve insicion & 8 & 1.3 \\
\hline & Dislocation & 4 & 0.7 \\
\hline
\end{tabular}

SMI: Simple medical intervention; STI: Soft tissue injury

served in both sexes equally. The difference between gender and diagnosis were not significant $(\mathrm{p}>0.05)$. The relationship between gender and patient characteristics are shown in Table 2.

The majority of patients admitted with a traffic accident and beaten entered to the ER between 16:00-24:00 o'clock but penetrating trauma and falling patients often entered to ER between the hours of 08:00 to 16:00 $(p<0.001)$. While the large number of patients discharged from the emergency department ( $\mathrm{n}=431,71.8 \%)$, two $(0.3 \%)$ patients died (Table 1$)$. The mechanism of injury was traffic accident in two patients who died $(\mathrm{p}<0.001)$. Table 3 shows the relationship between the characteristics of the mechanisms of injury and the patient.

\section{Discussion}

Trauma that led to death of approximately 150,000 people per year, remains one of the primary public health problems (Sauaia et al., 1995). The science of Orthopedics and Traumatology is not only interested in extremity injuries, but also other skeletal system injuries out of cranium. All physicians dealing with patients in a trauma are also in the judicial mechanism. (http://www.ctf.edu.tr/stek/pdfs/03/0308nk.pdf, 2013)

In trauma patients, the most common type of injury is the skeletal fractures and soft tissue injury. Extremity trau- 


\begin{tabular}{|c|c|c|c|c|}
\hline \multicolumn{2}{|l|}{ Patients characteristics } & \multicolumn{2}{|c|}{ Gender } & \multirow[t]{2}{*}{$\mathbf{p}$} \\
\hline \multirow{5}{*}{ Mechanism of injury } & & $\underset{\text { (n) }}{\text { Male }}$ & $\begin{array}{c}\text { Female } \\
\text { (n) }\end{array}$ & \\
\hline & Traffic accident & 164 & 70 & \multirow{4}{*}{$<0.001$} \\
\hline & Fall & 81 & 21 & \\
\hline & Assault & 60 & 14 & \\
\hline & $\begin{array}{l}\text { Penetrating } \\
\text { injury }\end{array}$ & 163 & 27 & \\
\hline \multirow{3}{*}{ Application hour groups } & 00:00-08:00 & 60 & 14 & \multirow{3}{*}{ NS } \\
\hline & 08:00-16:00 & 182 & 52 & \\
\hline & $16: 00-24: 00$ & 194 & 57 & \\
\hline \multirow{2}{*}{ Work accident } & Yes & 101 & 12 & \multirow{2}{*}{$<0.001$} \\
\hline & No & 367 & 120 & \\
\hline \multirow{2}{*}{ Life threatinig } & Yes & 37 & 8 & \multirow{2}{*}{ NS } \\
\hline & No & 431 & 124 & \\
\hline \multirow{4}{*}{ Outgrowth } & Discharged & 329 & 102 & \multirow{4}{*}{ NS } \\
\hline & Hospitalization & 132 & 30 & \\
\hline & Referral & 5 & 0 & \\
\hline & Exitus & 2 & 0 & \\
\hline \multirow{7}{*}{ Diagnosis } & STI & 115 & 46 & \multirow{7}{*}{ NS } \\
\hline & Tendon insicion & 36 & 6 & \\
\hline & Fracture & 131 & 139 & \\
\hline & $\begin{array}{l}\text { Skin-subcutan } \\
\text { insicion }\end{array}$ & 153 & 32 & \\
\hline & Amputation & 24 & 6 & \\
\hline & $\begin{array}{l}\text { Vessel-nerve } \\
\text { insicion }\end{array}$ & 7 & 1 & \\
\hline & Dislocation & 2 & 2 & \\
\hline
\end{tabular}

NS: Not Significance; STI: Soft Tissue Injury

ma injury patterns vary in a wide range from soft tissue injury to the amputations. These are the skin and subcutaneous incisions, tendon ruptures or incisions, vascular-nerve injuries, muscle ruptures or cuts, dislocations, fractures and amputations; these injuries may occur differently or combined traumas(http://www.ctf.edu.tr/stek/pdfs/03/0308nk.pdf,2013; http://www.klinikgelisim.org.tr/eskisayi/2008-4/12. pdf, 2013). In this study, the most common injuries are -in a similar way of the literature- skin and subcutaneous incisions, fractures and soft tissue injury.

Orthopedic injuries can affect all age groups up to neonates to geriatrics. In general, a large portion of trauma patients are young adults (Regel et al., 1995; Çakır et al., 2006). In a study by Varol et al. (2006); patients presenting to the emergency department with a traffic accident found that the average age was 30.6. 68\% of the patients were males. Many of in once were also in the younger age group. Almost more than $3 / 4$ of the patients' were males.

İn a study by Cakir et al. (2006) forensic reported traumas were found a $46.9 \%$ rate of hospitalization. We found the rate of hospitalization $27 \%$. The difference between our and Cakir et al's cases depends on characteristics of the traumas; all our cases have orthopedic injuries and orthopedics injured cases have lesser hospitalization indication. Also many of our cases were minor injuries like skin-incision and soft tissue injury that had lesser hospitalization indication. Because of the patients admitted with orthopedic injuries; the hospitalization was mostly done to the orthopedic clinic, plastic surgery clinic and rarely part to other clinics.

In a study by Güzel et al. (2007) reported that patients admitted to the emergency department the time zone when the event occurs most frequently in 18:00-24:00 hours reported. Similarly, in this study we found that the patients' application time to emergency service was mostly evening.

Orthopedic injuries may occur depending on road traffic accidents, falls, assault, firearm and stab (Çakır et al., 2009; Kandis et al., 2009). As all over the world, traffic accidents which are one of the most important public health problems cause 10.000 person/year series morbidities and 1000/year death; in our country (Soysal and Çakalır, 1991). In this study, the major mechanism of injury was traffic accidents.

Every year many people become disabled or die by work accident which may easily be prevented. Work-related accidents occur frequently in men (Yardım et al., 2007). This study, the cases with orthopedic injuries by accidents at work were about $1 / 5$, percent. The majority of them were males. When we think about the higher percentage of men in the work; it is usual that men have more injury from women.

It's wanted from physicians that if an injury removed Table 3. The relationship between the mechanism of injury and patients characteristics

\begin{tabular}{|c|c|c|c|c|c|c|}
\hline \multirow{2}{*}{$\begin{array}{l}\text { Patients characteristics } \\
\text { Traffic accident }\end{array}$} & & \multicolumn{4}{|c|}{ Mechanism of injury } & \multirow[b]{2}{*}{$p$} \\
\hline & & $\begin{array}{l}\text { Traffic accident } \\
\text { (n) }\end{array}$ & Fall & Assault & $\begin{array}{l}\text { Penetrating injury } \\
\text { (n) }\end{array}$ & \\
\hline \multirow{3}{*}{ Application hour groups } & 00:00-08:00 & 44 & 5 & 8 & 22 & \\
\hline & 08:00-16:00 & 90 & 50 & 22 & 88 & \\
\hline & $16: 00-24: 00$ & 100 & 47 & 44 & 80 & \\
\hline \multirow{2}{*}{ With SMI } & May be removed & 142 & 34 & 57 & 77 & \\
\hline & May not be removed & 90 & 68 & 17 & 113 & $<0.001$ \\
\hline \multirow{2}{*}{ Work accident } & Yes & 5 & 19 & 5 & 84 & \\
\hline & No & 229 & 83 & 69 & 106 & \\
\hline \multirow{4}{*}{ Outgrowth } & Discharged & 171 & 65 & 68 & 117 & \\
\hline & Hospitalization & 58 & 32 & 3 & 65 & \\
\hline & Refferral & 0 & 1 & 0 & 4 & \\
\hline & Exitus & 2 & 0 & 0 & 0 & \\
\hline
\end{tabular}


with a simple medical intervention or not while writing forensic report. Bone fractures are appreciated that not to be healed with a simple medical intervention (Balc1 et al., 2008). In a study by Bilgin et al. (2013) reported that healing rate of $63.5 \%$ with a simple medical intervention. In this study, half of patients can be corrected with a simple medical intervention. A very high proportion of patients were not in a life-threatening position. In this study characters that can be corrected with a simple medical intervention was low rated because of the trauma patients with orthopedic injury. When we look at the relationship of mechanism of injury and" healing with simple medical intervention"; while being beaten and traffic accidents may heal merely with simple medical intervention" falling and penetrating injuries were merely cannot be solved with a "simple medical intervention.
Orthopedic injuries which mostly caused by traffic accidents and penetrating traumas most often seen in middle-age groups; most of them don't have life threatening injuries. Extremity traumas are often related with other system injuries so that the trauma patients have to be examined by an experienced multidisciplinary team and the treatment has to be started as fast as possible.

As a result; extremity trauma cases brought to the emergency room for trauma has to be known by a special case by medical doctors, more comprehensive medical history should be taken and physical examination should be done systematically not only for the extremities. Also the following or needing control in early period patients with extremity trauma and associated traumas should not be avoided from hospitalization.

\section{REFERENCES}

Balcı, Y., Güzel, S., Çetin, G., 2008. Yeni Türk Ceza Kanunu'ndatanımlanan yaralama suçlarının adli tıp açısından değerlendirilmesi. In: Balcı Y, editör. Herkes için adli tıp cep kitabı. Eskişehir: Osmangazi Üniversitesi Yayınları. p.p: 203-235.

Bayram, B. 2013. Yetişkinlerde travma. Eds: Çete, Y., Denizbaşı, A., Çevik, A.A., Oktay, C., Atilla, R. Acil Tıp. Kapsamlı bir çalışma kılavuzu. İstanbul: Nobel Tip Kitabevleri. p.p: 1671-1676.

Bilgin, U.E., Meral, O., Koçak, A., Aktaş, E.Ö., Kıyan, S., Altuncı, Y.A., 2013. 2011 yılında trafik kazası sonucu Ege Üniversitesi Hastanesi Acil Servisine başvuran hastaların adli tıbbi boyutuyla incelenmesi. Ege Tıp Dergisi. 52, 93-99.

Çakır, Z., Aslan, Ş., Bilir, Ö., ve ark., 2006. Acil servise başvuran adli nitelikteki travma vakalarının geriye dönük analizi. Akademik Acil Tıp Dergisi. 6, 32-37.

Çakır, Z., Aslan, Ş., Çakır, M., Sarıtaş, A., Emet, M., Tan, Ö., 2009. An Accident Due to an Unusual Mausetrap. Turk J. Emerg Med. 9, $36-39$.

Güzel, A., Karasalihoğlu, S., Küçükuğurluoğlu, Y., 2007. Çocuk acil ünitemize düşme nedeniyle başvuran travma olgularının değerlendirilmesi. Ulus Travma Acil Cerrahi Derg. 13, 211-216.

http://www.ctf.edu.tr/stek/pdfs/03/0308nk. Access date: 05.08.2013.

http://www.klinikgelisim.org.tr/eskisayi/2008-4/12. Access date: 05.08.2013.

Jones, K.W., 1980. Thoracic trauma. Surg Clin North Am. 60, 957-981.

Kandis, H., Gungor, A., Katirci, Y., Deniz, H., Deniz, T., 2009. Göğüs travmalı olguların demografik özellikleri. Türkiye Acil Tıp Dergisi. 19-23.

Kandiş, H., Katırc1, Y., Sarıtaş, A., Kaya, H., 2009. Luxatio Erecta Olgusu. JAEM. 8:4:7-8. doi:10.4170/JAEM.2009.21939.

Regel, G., Lobenhoffer, P., Grotz, M., Pape, H.C., Lehmann, U., Tscherne, H., 1995. Treatment results of patients with multiple trauma: an analysis of 3406 cases treated between 1972 and 1991 at a German Level I Trauma Center. J. Trauma. 38, 70-78.

Sauaia, A., Moore, F.A., Moore, E.E., et al., 1995. Epidemiology of trauma deaths: A reassessment. J. Trauma. 38, 185-93.

Soysal, Z., Çakalır, C., 1991. Adli Tıp İstanbul Üniversitesi Cerrahpaşa Tıp Fakültesi Yayınları Rektörlük No:4165. Fakülte No:224. İstanbul. 595.

Varol, O., Eren, H.Ş., Oğuztürk, H., Korkmaz, İ., Beydilli, İ., 2006. Acil servise trafik kazası sonucu başvuran hastaların incelenmesi. Cumhuriyet Üniv. Tıp Fak. Derg. 28, 55-60.

Yardım, N., Çipil, Z., Vardar, C., Mollahaliloğlu, S., 2007. Türkiye İş Kazaları ve Meslek Hastalıkları: 2000-2005 Yılları Ölüm Hızları. Dicle Tip Derg. 34, 264-271. 